Таким образом, особенности функционирования рыночной терминологии в сфере государственного управления современной России, с одной стороны, отражают процессы ослабления регулирующего воздействия государственного управления на систему современного рынка, a c другой стороны, подтверждают активное использование методов и принципов рынка в новой модели отечественного государственного управления.

$$
* * *
$$

1. Лазарев А. М. Концептуальные основы и практика современного административного реформирования (сравнительно-политологический анализ): дис. канд. политич. наук/ А.М. Лазарев. - М, 2009.

2. Заварзина Г.А. Русская лексика государственного управления: история формирования и современные процессы развития: дис. доктора...филол. наук. - Воронеж, 2015. - 381 с.

3. Егоров В.С. Государственная служба сегодня подменяет государственное управление//Независимая газета. - 02.11.2000. - С.2-4.

4. Zavarzina G.A. Actual problems of terminological system development of new state administration / G.A. Zavarzina, T.N. Dankova// The International Scientific and Practical Conference "Current Issues of Linguistics and Didactics: The Interdisciplinary Approach in Humanities and Social Sciences”. - Volume 69. -2019.

5. Заварзина Г.А. Новые системные связи в структуре ЛСП «Государственное управление» // Современные проблемы лингвистики и методики преподавания русского языка в вузе и школе. Выпуск 27. - Воронеж: ИПЦ «Научная книга», 2017. - С. 3-5.

\title{
Коляда Н.А. \\ Значимость развития навыков межкультурного общения при обучении иностранным языкам
}

Южный Федеральный университет (Россия, Ростов-на-Дону)

doi 10.18411/gq-31-03-2021-57

idsp sciencerussia-31-03-2021-57

\section{Аннотация}

Рассматривается преподавание иностранного языка как средства повседневного общения с носителями другой культуры. Особое внимание уделяется межкультурному обучению, способствующему достижению межкультурной коммуникации. Предлагаются возможности для развития способностей и навыков межкультурного общения с привлечением материала лингвострановедческого содержания, приводятся примеры упражнений для развития и закрепления навыков межкультурного общения, направленные на умение интерпретировать существующие различные модели восприятия мира, соотносить иные культурные обычаи и нравы со своими поведенческими нормами.

Ключевые слова: иноязычная коммуникация, концепция коммуникативного обучения, лингвострановедческий материал, культура и язык.

\section{Abstract}

The article considers teaching a foreign language as a means of everyday communication with native speakers of another culture. Special attention is paid to crosscultural learning, which contributes to the achievement of cross-cultural communication. The article offers opportunities for developing the abilities and skills of cross-cultural communication with the involvement of the material of linguistic and cultural content, provides examples of exercises for the development and consolidation of cross-cultural communication skills, aimed at the ability to interpret the existing various models of perception of the world, to relate other cultural customs and mores with their behavioral norms.

Keywords: foreign language communication, the concept of communicative learning, linguistic and foreign studies material, culture and language. 
Отечественная методика преподавания иностранных языков бесконечно совершенствуется и предлагает множество рекомендаций и указаний для достижения поставленных целей. Длительное время основная направленность при обучении иностранным языкам в высших учебных заведениях носила профессиональноориентированный характер. Целью такого обучения являлось, в первую очередь, развитие способностей и готовности к иноязычной речевой деятельности для делового межкультурного общения, участия в международных конференциях, симпозиумах. Предполагалось, что выпускник вуза должен уметь вести диалог, дискуссии по научным проблемам в рамках его специализации [1].

Однако, жизнь диктует свои требования, и уже становится недостаточным владение только профессиональным языком. Важным фактором при этом все настоятельнее выступает формирование иноязычной коммуникативной компетенции в межкультурном общении. Иными словами, преподавание иностранного языка должно быть направлено на овладение иностранным языком как средством повседневного общения с носителями другой культуры, что требует, в свою очередь, становления способности обучаемого к межкультурной коммуникации.

Термин «коммуникация», появившийся в начале $\mathrm{XX}$ века и рассматривающийся в научной литературе в большей мере учеными- философами, культурологами, сводился к понятию обмена информацией в рамках знаковой системы как вербальных, так и невербальных средств общения.

Следует заметить, что коммуникативную и самую важную, первостепенную функцию в процессе человеческой деятельности и по сей день выполняет язык, который помогает человеку формировать представление об окружающем мире.

Именно общение людей при помощи языка принято в науке считать языковой коммуникацией, а каждый случай такого общения принято называть актом коммуникации (КА).

В процессе преподавания иностранных языков теоретики-практики разрабатываю новые методики, выдвигая при этом во главу угла все больше и больше концепцию коммуникативного обучения. Коммуникативная основа при изучении иностранного языка становится нормативным требованием к организации успешного обучения, основанного на заданиях коммуникативного характера, то есть общения, которое приравнивают к межкультурной коммуникации [2].

Актуальность в этой связи заключается в значимости так называемого межкультурного подхода, к которому обращаются многие российские исследователи. Выше названный подход имеет своей целью формирование и развитие межкультурной компетенции для осуществления взаимодействия с представителями разных культур, стран, социумов.

При изучении иностранного языка обучающийся непременно сталкивается с культурой того или иного народа, язык которого им изучается. Расширение межкультурных контактов, информационный поток, как особый обмен информацией и способ общения, заставляет изменить представление о межкультурном общении [3]. Иными словами, для снятия трудностей по данному вопросу является необходимость изучать иностранный язык в неразрывном единстве с миром и культурой народа, изучаемого языка, так как межкультурная коммуникация - это общение между людьми из разных культур [4].

К основным компонентам приобщения к культуре другого народа относят такие, как традиции, обычаи, праздники; нормы повседневного общения, правила поведения в общественных места, формы приветствия, прощания; знакомство с культурным наследием народа, то есть все то, что составляет своеобразную национальноспецифическую характеристику народа. В этой связи особое внимание исследователей по данному вопросу уделяется проблеме интеграции компонентов культуры народа изучаемого языка в обучение иностранному языку. Целью коммуникативной методики 
становится не просто научить владеть иностранным языком, а приобщить к иноязычной культуре, включающей в себя ряд аспектов, как-то: познавательный, воспитательный, развивающий, учебный [5]. Процесс обучения иностранным языкам в последнее время рассматривается как изучение языка и культуры. На занятиях по иностранному языку стремятся не только научить обучающихся владению умениями и как задавать вопросы, и как активно участвовать в беседе, расширяя свои вопросырасспросы; умению строить собственные аргументации по тому или иному вопросу беседы, умению противопоставить собственную информацию информации собеседника.

С учетом того факта, что обучение иностранному языку происходит в так называемой «Искусственной среде», разрабатывается методистами и практиками комплекс упражнений коммуникативного характера с целью достижения межкультурной коммуникации. Примером тому могут служить упражнения не занятиях при изучении иностранного языка на тему «Народные традиции»:

№ 1

a) Ознакомьтесь с такой традицией как «Крещение».

Б) Выскажите свое мнение о значимости крещения в жизни человека. Играет ли эта традиция какую-либо роль для счастливой жизни или вообще не имеет никакого значения

в. Поговорите на тему «Есть ли в Вашей стране такая традиция? Крещенный ли Вы? Почему? Есть различия в этой традиции в Вашей стране в стране изучаемого Вами языка? Какие?

№ 2

а) Ознакомьтесь с такой традицией как «Свадьба. Обручение»

б) Какие традиции и обычаи существуют в Вашей стране?

в) Выскажите свое мнение о такой традиции как «Обручение». Существует ли в Вашей стране такая традиция?

№ 3 На основании предложенного текста «Что говорят иностранцы о культуре быта Вашей страны» выразите свое мнение по некоторым вопросам:

a) Как бы Вы описали иностранцу свою страну?

б) Как Вы воспринимаете кулинарные изыски других стран?

в) Как Вы встречаете дома своих гостей? Что Вы им предлагаете? Есть ли какието традиции приема гостей?

Преподавание иностранного языка предполагает привить обучающимся не только знания лексического и грамматического материала изучаемого языка, не только умение построить вопросы и ответы, но донести на занятиях информацию о культуре быта страны изучаемого языка, о культурном наследии, которое является вкладом в мировую сокровищницу.

Таким образом, лингвострановедческая работа преподавателя иностранного языка, страноведческий аспект является не добавлением к учебному процессу, а неотъемлемой его частью для обмена устной и письменной информацией, расширения кругозора, границ восприятия и мироощущения.

Упражнения должны быть направлены при деловом общении на правильные манеры приветствия, обращения к незнакомым лицам, к представителям фирм, с которыми в будущем будут сотрудничать обучающиеся или принимать участие в конференциях, симпозиумах и других официальных мероприятиях. При этом необходимо познакомить обучающихся с этикетом приветствия и прощания, написания деловых писем.

Так, например, в Германии принято обращаться не по имени, отчеству, как в России, а называя ученую степень или научное звание, господин или госпожа + фамилия. 
При переписке по электронной почте необходимо знать, как следует оформлять письмо, как обратиться и как прощаться, так как в каждых странах есть определенные нормы, которых следует придерживаться. Важно также знать, что на любое письмо необходимо ответить, даже если ответ отрицательный.

Следует также познакомить обучающихся с нормами повседневного быта. Например, по вопросам, как и когда следует приходить в гости при приватном приглашении или на официальный прием, на званный обед, на который опаздывать нельзя, или на вечеринку. Не мало важным фактором является и вопрос, расположения гостей за столом. В некоторых странах существует обычай расставлять на столе карточки с именем, фамилией или званием гостей. По этому поводу может быть предложен целый ряд упражнений относительно высказывания по данному вопросу. Например. почему это имеет смыл при приеме гостей и какую цель данный метод преследует.

При этом следует донести до обучающихся сведения, как и в каком виде следует дарить цветы: если, например, в каких-то странах роль играет чет или нечет количества цветов, а в Вашей стране это роли не играет.

Интерес всегда вызывает и вопрос, как преподносятся подарки. При этом могут предложены упражнения на высказывание своего мнения относительного таких вопросов, как:

- пишите ли Вы свои пожелания при дарении книги в саму книгу или следует вложить открытку с пожеланиями,

- согласны ли Вы с тем, что подарок следует раскрывать в присутствии гостей,

— существенны ля для Вас критерии выбора подарка.

В последнее время многие выпускники вузов предпочитают работать за границей. Преподаватель должен на занятиях затронуть вопрос, какие требования могут быть предъявлены при собеседовании. В некоторых странах на это особенное внимание не обращают. Но в некоторых странах не малую роль при собеседовании играет следующее:

— внешний вид претендента на работу

— пунктуальность

— осведомленность о фирме, в которой претендент хотел бы получить работу

- манера поведения и ведения беседы.

Подача заявления на работу может совершаться либо в письменной, либо в устной форме, например по телефону. Следовательно. на занятиях следует предложить упражнения на тренировку телефонных разговоров: обращение, изложение проблемы и прощание.

В свете расширения контактов между странами и возможности обучаться за рубежом необходимо на занятиях ознакомить обучающихся. Как составить запрос, какие документы должны быть представлены и как оформлены.

Bсе вышеизложенное свидетельствует о том, какой настоятельной необходимостью наделяется не только лингвострановедческий аспект в преподавании иностранных языков, но и такой вид работы на занятиях по иностранному языку как деловой иностранный язык в сфере профессионального общения.

The Russian methodology of teaching foreign languages is constantly improving and offers many recommendations and guidelines for achieving the goals set. For a long time, the main focus in teaching foreign languages in higher educational institutions was professionally oriented. The purpose of such training was, first of all, the development of abilities and readiness for foreign language speech activity for business intercultural communication, 
participation in international conferences, symposiums. It was assumed that a graduate of the university should be able to conduct a dialogue, discussions on scientific problems within the framework of his specialization [1].

However, life dictates its own requirements, and it is already becoming insufficient to speak only a professional language. An important factor in this case is the formation of foreign-language communicative competence in intercultural communication. In other words, teaching a foreign language should be aimed at mastering a foreign language as a means of everyday communication with native speakers of another culture, which in turn requires the development of the student's ability to cross-cultural communication.

The term "communication", which appeared at the beginning of the XX century and is considered in the scientific literature to a greater extent by scientists - philosophers, cultural scientists, was reduced to the concept of information exchange within the sign system of both verbal and non-verbal means of communication.

It should be noted that the communicative and most important, primary function in the process of human activity is still performed by language, which helps a person to form an idea of the world around him.

It is the communication of people with the help of language that is considered in science to be language communication, and each case of such communication is called an act of communication( KA).

In the process of teaching foreign languages, theorists and practitioners develop new methods, while putting the concept of communicative learning more and more at the forefront. The communicative basis in the study of a foreign language becomes a normative requirement for the organization of successful training based on tasks of a communicative nature, that is, communication, which is equated with intercultural communication [2].

The relevance in this regard lies in the importance of the so-called cross-cultural approach, which is addressed by many Russian researchers. The above-mentioned approach is aimed at the formation and development of cross-cultural competence for interaction with representatives of different cultures, countries, and societies.

When learning a foreign language, the student is certainly faced with the culture of a particular people, the language of which he is studying. The expansion of cross-cultural contacts, the information flow, as a special exchange of information and a way of communication, forces us to change the idea of cross-cultural communication [3]. In other words, to remove difficulties on this issue, it is necessary to study a foreign language in inseparable unity with the world and culture of the people, the language being studied, since intercultural communication is communication between people from different cultures [4].

The main components of familiarization with the culture of another people include such as traditions, customs, holidays; norms of everyday communication, rules of behavior in public places, forms of greeting, farewell; acquaintance with the cultural heritage of the people, that is, everything that makes up a kind of national-specific characteristic of the people. In this regard, special attention of researchers on this issue is paid to the problem of integrating the components of the culture of the people of the studied language into the teaching of a foreign language. The goal of the communicative methodology is not just to teach a foreign language, but to introduce it to a foreign language culture, which includes a number of aspects, such as: cognitive, educational, developing, educational [5]. The process of teaching foreign languages has recently been considered as the study of language and culture. In foreign language classes, they try not only to teach students how to master the skills and how to ask questions, but also how to actively participate in the conversation, expanding their questions-questions; the ability to build their own arguments on a particular issue of the conversation, the ability to contrast their own information with the information of the interlocutor.

Taking into account the fact that teaching a foreign language takes place in the socalled "Artificial Environment", methodologists and practitioners develop a set of exercises of 
a communicative nature in order to achieve intercultural communication. An example of this is the exercises in the classroom when learning a foreign language on the topic "Folk traditions":

No. 1

a) Get acquainted with such a tradition as "Baptism".

b) Express your opinion about the significance of baptism in a person's life. Does this tradition play any role for a happy life or does it have no meaning

at all? Talk about the topic "Is there such a tradition in your country? Are you baptized? Why? Are there differences in this tradition in your country in the country of the language you are studying? Which ones?

No. 2

a) Get acquainted with such a tradition as " Wedding. Betrothal "

b) What traditions and customs exist in your country?

c) Express your opinion about such a tradition as "Betrothal". Is there such a tradition in your country?

\# 3 On the basis of the proposed text "What do foreigners say about the culture of your country", express your opinion on some questions:

a) How would you describe your country to a foreigner?

b) How do you perceive the culinary delights of other countries?

c) How do you meet your guests at home? What do you offer them? Are there any traditions of receiving guests?

Teaching a foreign language involves instilling in students not only knowledge of the lexical and grammatical material of the language being studied, not only the ability to construct questions and answers, but also to convey information about the culture of the country of the language being studied, about the cultural heritage, which is a contribution to the world treasury.

Thus, the linguistic and country studies work of a foreign language teacher, the country studies aspect is not an addition to the educational process, but an integral part of it for the exchange of oral and written information, expanding the horizons, the boundaries of perception and perception of the world.

The exercises should be aimed at business communication in the correct manner of greeting, addressing strangers, to representatives of companies with which students will cooperate in the future or take part in conferences, symposiums and other official events. At the same time, it is necessary to introduce students to the etiquette of greeting and saying goodbye, writing business letters.

So, for example, in Germany, it is customary to address not by first name, patronymic, as in Russia, but by calling an academic degree or scientific title, Mr. or mrs. + last name.

When communicating by e-mail, you need to know how to write a letter, how to address it, and how to say goodbye, since each country has certain rules that should be followed. It is also important to know that any email must be answered, even if the answer is negative.

Students should also be introduced to the norms of everyday life. For example, on questions about how and when to come to visit with a private invitation or for an official reception, for a dinner party that you can not be late for, or for a party. Not a little important factor is the question of the location of guests at the table. In some countries, it is customary to place cards on the table with the name, surname or title of guests. On this occasion, a number of exercises can be proposed regarding the statement on this issue. For example. why does this make sense when receiving guests and what is the purpose of this method?

At the same time, it is necessary to inform the students about how and in what form flowers should be given: if, for example, in some countries the number of flowers is even or odd, but in your country this does not matter. 
The question of how gifts are presented is always of interest. At the same time, exercises can be offered to express your opinion on such issues as:

- do you write your wishes when giving a book in the book itself, or should you attach a card with your wishes,

- do you agree that the gift should be opened in the presence of guests,

- whether the criteria for choosing a gift are essential for you.

Recently, many university graduates prefer to work abroad. The teacher should raise the question of what requirements can be presented during the interview. In some countries, this is not particularly paid attention to. But in some countries, not a small role in the interview is played by the following:

- appearance of the applicant for the job

- punctuality

- awareness of the company in which the applicant would like to get a job

- the manner of behavior and conversation.

The application for a job can be made either in writing or orally, for example, by phone. Therefore. In the classroom, you should offer exercises for training telephone conversations: addressing, presenting the problem and saying goodbye.

All of the above points to the urgent need not only for the linguistic and cultural aspect of teaching foreign languages, but also for such a type of work in foreign language classes as a business foreign language in the field of professional communication.

1. Коляда Н. А. Язык - Принцип коммуникативности в обучении иностранным языкам / Н. А. Коляда // Актуальные вопросы филологии и методики преподавания иностранных языков. Межвузовский сборник научных статей. Выпуск 8. - Ростов-на-Дону: Ростовский институт иностранных языков. - 2010. - C. 91 - 98. ISBN 5-85216-064-9

2. https://moluch-ru/81/19848/ (дата обращения: октябрь, 2020)

3. Особенности общения в современном мире. [Электронный pecypc] - www.refdb.ru (дата обращения, 25.08.2016)

4. Психология и культура. [Электронный pecypc] -https//shulenina.narod.ru (дата обращения март 2010).

5. Сравнительная характеристика современных методик преподавания английского языка. [Электронный pecypc] -https//bestreferat.ru (дата обращения март 2010).

\section{Ткачёва Р.А., Мирзоева В.М., Михайлова Н.Д., Шоайб А. Улыбка как невербальное средство в межкультурном общении}

ФГБОУ ВО Тверской ГМУ Минздрава России (Россия, Тверь)

doi $10.18411 / g q-31-03-2021-58$

idsp sciencerussia-31-03-2021-58

\section{Аннотация}

Статья посвящена улыбке как невербальному средству в межкультурном общении. Авторы рассматривают проблему формирования толерантного сознания у иностранных студентов на основе расширения их коммуникативной компетентности в понимании особенностей национальной культуры разных народов, в том числе русской. В статье отмечается, что в культуре разных народов улыбка имеет свои коммуникативные особенности, возможности и цели. Особое внимание уделяется роли улыбки в профессиональной деятельности врача. В статье обращается внимание на причины бытовой неулыбчивости русского человека, связанные с традициями русской коммуникации и отразившиеся в пословицах и поговорках. Авторы приходят к выводу, что знание особенностей национальной коммуникативной культуры разных народов, в 